\title{
Vitamin D status and attitudes towards sun exposure in South Asian women living in Auckland, New Zealand
}

\author{
Pamela R von Hurst ${ }^{1}$, Welma Stonehouse ${ }^{1}$ and Jane Coad $^{2, *}$ \\ ${ }^{1}$ Institute of Food, Nutrition and Human Health, Massey University, Auckland, New Zealand: ${ }^{2}$ Institute of Food, \\ Nutrition and Human Health, Massey University, Private Bag 11222, Palmerston North, New Zealand
}

Submitted 28 August 2008: Accepted 15 June 2009: First published online 4 August 2009

\begin{abstract}
Objective: To determine the vitamin D status of women of South Asian origin living in Auckland, New Zealand, and to investigate their attitudes and behaviours with regard to sun exposure.

Design: Cross-sectional study. Setting: Auckland, New Zealand.

Subjects: Women of South Asian origin ( $n$ 235) aged 20 years and older were tested for serum $25(\mathrm{OH}) \mathrm{D}$, and 228 were included in these analyses. Of these, 140 completed a questionnaire about attitudes and behaviours to sun exposure, and health motivation. Exclusion criteria included high dose $(>1000 \mathrm{IU} / \mathrm{d})$ supplementation with $25(\mathrm{OH}) \mathrm{D}_{3}$, or any supplementation with $1,25(\mathrm{OH})_{2} \mathrm{D}_{3}$.

Results: As serum vitamin D concentrations were not normally distributed, data are reported as median (25th, 75th percentile). Median serum $25(\mathrm{OH}) \mathrm{D}_{3}$ was $27 \cdot 5(18 \cdot 0$, $41 \cdot 0) \mathrm{nmol} / \mathrm{l}$. Adequate concentrations $(>50 \mathrm{nmol} / \mathrm{l})$ were observed in only $16 \%$ of the subjects. Concern about skin cancer and the strength of the New Zealand sun were the most prevalent reasons given for sun avoidance, with $65 \%$ saying they did avoid the sun. However, a seasonal variation was observed, with concentrations reducing significantly $(P<0 \cdot 001)$ from summer through to early spring by $19.5 \mathrm{nmol} / \mathrm{l}$.

Conclusions: The results of the present study suggest that South Asian women are at high risk of hypovitaminosis $\mathrm{D}$, due, in part, to deliberate sun avoidance and an indoor lifestyle, and that they are especially vulnerable in winter and spring.
\end{abstract}

\author{
Keywords \\ Vitamin D \\ South Asian \\ Sun exposure
}

Worldwide, there have been increasing concerns about hypovitaminosis $\mathrm{D}$ with high rates of deficiency reported in both developing and developed countries ${ }^{(1)}$. Infantile rickets and osteomalacia are re-emerging throughout the United Kingdom, Northern Europe, USA, Saudi Arabia ${ }^{(2-4)}$, and even in temperate and sub-tropical countries like New Zealand and Australia ${ }^{(5-7)}$.

New Zealand lies in the South Pacific between the latitudes of $34^{\circ} \mathrm{S}$ and $47^{\circ} \mathrm{S}^{(8)}$, and has very high levels of solar radiation during summer ${ }^{(9)}$. However, there is increasing evidence of widespread hypovitaminosis $\mathrm{D}$, with some ethnic groups appearing to be at higher risk ${ }^{(10-12)}$.

Over the last decade, immigration to New Zealand from the Indian sub-continent and Sri Lanka, generally referred to as South Asia, has more than doubled. According to the 2006 census, the number of people of South Asian origin now living in New Zealand is over 113000 and the majority (70\%) are resident in Auckland ${ }^{(13)}$. There have been similar patterns of migration from India into Australia ${ }^{(14)}$. To date there has been no assessment of the vitamin D status of South Asians living in New Zealand.
The potential consequences of inadequate vitamin D are now known to extend beyond poor bone health. Vitamin D deficiency has been implicated in age-related muscle loss and the development of sarcopenia ${ }^{(15)}$, cancer $^{(16)}$ CVD $^{(17)}$, auto-immune conditions ${ }^{(18,19)}$ and type 2 diabetes $^{(20)}$. In New Zealand, the prevalence of some of these diseases in South Asians is considerably higher than that of the general population. The 2006 Asian Health Chart Book ${ }^{(21)}$, the first comprehensive survey of the health of Asian people living in New Zealand, documents self-reported incidence of type 2 diabetes in the South Asian population as being three times the national average, and hospitalisation and mortality due to CVD or IHD as approximately double.

\begin{abstract}
Aim
The aim of the present study was to determine the vitamin D status of women of South Asian origin living in Auckland, New Zealand, and to investigate their attitudes and behaviours with regard to sun exposure.
\end{abstract}




\section{Method}

The methodology is reported in greater detail elsewhere $^{(22)}$. In brief, the study was promoted in media intended for an Indian and South Asian audience, as well as through community groups, temples and local medical centres. Exclusion criteria included taking a prescription dose of cholecalciferol $(>1000 \mathrm{IU} / \mathrm{d})$ or any supplementation with $1,25(\mathrm{OH})_{2} \mathrm{D}_{3}$, major systemic illness, chronic kidney disease, diabetes, $<20$ years of age. Ethnicity was confirmed with a questionnaire which established country of birth for subject, her parents and all grandparents. Demographic information, medical history, nutritional supplement and medication use were obtained by interviewer-based questionnaires.

Screening commenced in February 2007 (NZ summer) and continued through the winter into early spring. To test the effect of seasonal variation on vitamin D status, the screening period was divided into seasons: February and March were deemed to be summer; April and May, autumn; June to August, winter; and September to November, spring. Serum 25(OH)D was measured using a DiaSorin double antibody radio-immunoassay. Participants were asked to complete a web-based questionnaire about attitudes and behaviours relating to sun exposure and health motivation. The six health motivation questions were a sub-set of a larger questionnaire, the Osteoporosis Health Belief Survey, which is subject to copyright and was used with permission of the developers ${ }^{(23)}$. The sun exposure questions were developed for the present study, and consisted of seven statements with pre-set response options plus a section for free comments. These questions were tested in a focus group of South Asian women to ensure that all options were covered, that the questions were understood, and none caused offence. Subjects were also asked to complete a $4 \mathrm{~d}$ food diary. These were analysed using Foodworks 2007 (Xyris Software, Queensland, Australia), New Zealand Foods Data Base.

Statistical analysis was performed using SPSS statistical software package version 15 (SPSS Inc., Chicago, IL, USA). $25(\mathrm{OH}) \mathrm{D}$ was not normally distributed, so non-parametric tests were used where applicable. The data are reported as frequencies, median (25th, 75 th percentile) or mean and SD. Mann-Whitney $U$ and Kruskal-Wallis $H$ tests were used to compare groups, and Spearmans for correlations.

\section{Results}

The majority of participants (91\%) were from India, with $6 \%$ from Sri Lanka and 3\% from Pakistan. These proportions reflect those reported in the 2006 census for the South Asian population ${ }^{(13)}$. In all, $79 \%$ were recent migrants, having been in New Zealand for $\leq 10$ years. The mean age was $40 \cdot 6$ (sD $10 \cdot 3$ ) years. There was a high level of education reported, with $75 \%$ having $\geq 15$ years of education from the age of 5 years, as expected from a newly migrant population, given New Zealand's immigration requirements for high educational standards. Of the 250 women screened for entry into the study, five were excluded for use of the $50000 \mathrm{IU}$ supplement, which is only available on doctor's prescription; three due to illness or use of other medication; and seven due to haemolysed blood sample.

Over a period of 9 months, serum 25(OH)D samples were obtained from 235 women. Serum 25(OH)D concentrations in seven women were over $72 \mathrm{nmol} / 1$ and, upon further investigation, it was discovered that all these women had been taking the 50000 IU supplement, 1-2 months prior to recruitment. The exclusion criteria precluded anyone currently taking supplements $>1000 \mathrm{IU} / \mathrm{d}$, but due to the long half-life $(\sim 90 \mathrm{~d})$ of $25(\mathrm{OH}) \mathrm{D}^{(24)}$, the $50000 \mathrm{IU}$ supplements have a longer-lasting effect than anticipated. Consequently, these seven women have not been included in the analysis below. An additional thirtythree women reported either very recent or current use of some form of vitamin D supplementation, including cod liver oil and multivitamins. The median $25(\mathrm{OH}) \mathrm{D}$ concentrations of these women was $38(24,59) \mathrm{nmol} / \mathrm{l}$, significantly higher than those taking no supplements $27(17,40) \mathrm{nmol} / \mathrm{l}(P<0 \cdot 001)$. The dose available in the dietary supplements reported ranged from $1 \cdot 2 \mu \mathrm{g}$ (48 IU) in cod-liver oil capsules, to $10 \mu \mathrm{g}$ (400 IU) in multivitamins.

The median serum $25(\mathrm{OH}) \mathrm{D}$ concentration of the study group ( $n$ 228) was $27 \cdot 5(18 \cdot 0,41 \cdot 0) \mathrm{nmol} / \mathrm{l}$. Only $16 \%$ of the participants were vitamin $D$ sufficient according to the current reference concentration of $\geq 50 \mathrm{nmol} / \mathrm{l}$. In all, $43 \%$ of the participants had concentrations less than $25 \mathrm{nmol} / \mathrm{l}$, which are associated with reduced bone mineral density and increased risk of fracture ${ }^{(25)}$. Vitamin D stores were at their peak in summer and

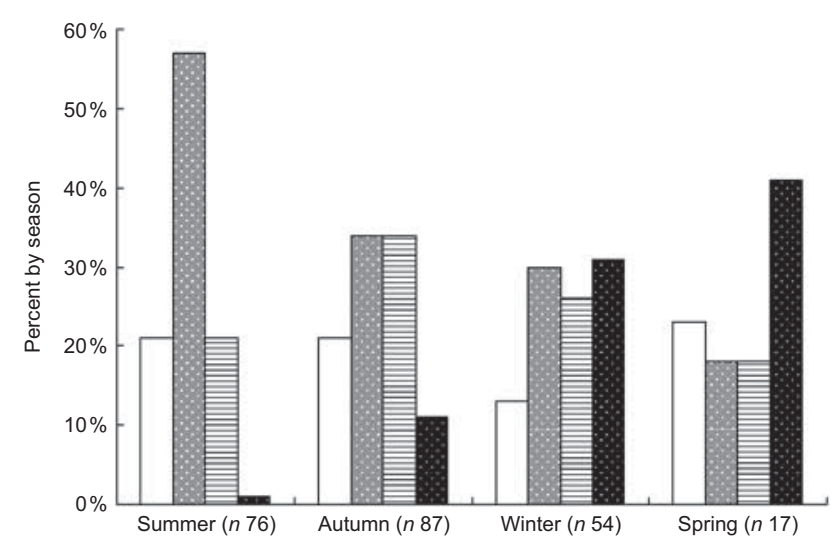

Fig. 1 Levels of deficiency or adequacy by season. Bars indicate percentage of subjects tested in that season $(\square$, adequate; $\times$, mild; $\Xi$, moderate;. , severe). Classification of serum $25(\mathrm{OH}) \mathrm{D}_{3}$ levels of deficiency/sufficiency as per cut-offs from the Working Group of the Australian and New Zealand Bone and Mineral Society et al. ${ }^{(25)}$ : severe deficiency $<12.5 \mathrm{nmol} / \mathrm{l}$, moderate deficiency $12.5-24.9 \mathrm{nmol} / \mathrm{l}$, mild deficiency $25 \cdot 0-50 \mathrm{nmol} / \mathrm{l}$, adequate $>50 \mathrm{nmol} / \mathrm{l}$ 
reached the nadir by spring (Fig. 1). Median levels by season were: summer, $33 \cdot 5(25 \cdot 7,46 \cdot 2) \mathrm{nmol} / \mathrm{l}$; autumn, $27 \cdot 0(18 \cdot 0,41 \cdot 0) \mathrm{nmol} / \mathrm{l}$; winter, $18 \cdot 0(11 \cdot 0,37 \cdot 0) \mathrm{nmol} / \mathrm{l}$; and spring, $13 \cdot 0(8 \cdot 5,30 \cdot 0) \mathrm{nmol} / \mathrm{l}$. Significant differences were observed in median $25(\mathrm{OH}) \mathrm{D}$ concentration between summer and winter, and autumn and winter (Mann-Whitney test, Bonferroni adjusted; $P$ value for multiple comparisons, significance $=P<0 \cdot 01$ ). There was a significant inverse correlation between parathyroid hormone $(\mathrm{PTH})$ and serum $25(\mathrm{OH}) \mathrm{D}_{3}$ concentration $(r=-0 \cdot 372, P<0 \cdot 001)$, mean PTH $5 \cdot 0(2 \cdot 2) \mathrm{pmol} / \mathrm{l}$.

Despite very determined follow-up, we were able to retrieve completed food diaries from only 139 subjects. These were analysed for the dietary contribution of vitamin $\mathrm{D}$. Median dietary intake of vitamin $\mathrm{D}$ was 0.84 $(0 \cdot 31,1 \cdot 89) \mu \mathrm{g} / \mathrm{d}$ or $33 \cdot 6(12 \cdot 4,75 \cdot 6) \mathrm{IU} / \mathrm{d}$. When dietary supplements were reported they were included in the assessment of dietary intake of vitamin $\mathrm{D}$, and the maximum mean daily intake (including supplements) was $8 \cdot 41 \mu \mathrm{g}$.

Responses from the 141 women who answered the sun exposure questions are shown in Table 1. With the exception of question 3, there was no correlation between the responses to these questions and vitamin $\mathrm{D}$ status. The serum vitamin $\mathrm{D}$ concentrations were significantly higher $(P=0 \cdot 013)$ in the respondents who said that they 'enjoyed spending time in the sun' $(35(22 \cdot 0,53 \cdot 7) \mathrm{nmol} / \mathrm{l})$ compared to those who said they rarely $(26 \cdot 5(18 \cdot 0,35 \cdot 7) \mathrm{nmol} / \mathrm{l})$ or never $(19 \cdot 5(16 \cdot 5,27 \cdot 7) \mathrm{nmol} / \mathrm{l})$ 'enjoyed spending time in the sun'.

Of the sixty-nine women who chose to make further comments, $42 \%$ remarked on the strength of the sun in New Zealand, the ozone hole and cancer risk. Five women said that they found New Zealand to be too cold, and were always covered by clothing when they went outside.

Responses to the Health Motivation section are shown in Table 2. Only statement 5, regarding having regular health check-ups, attracted a high level of disagreement (41.9\%). Internal reliability of this subsection was acceptable with a Cronbach's $\alpha$ value of $0 \cdot 7$.

\section{Discussion}

Due to the method of participant recruitment, this is not a randomised sample. However, that $84 \%$ were found to have

Table 1 Responses to the questionnaire on attitudes and behaviour regarding sun exposure ( $n$ 140)

\begin{tabular}{|c|c|c|}
\hline Sun exposure questions & Response & $\%$ \\
\hline 1. I believe that sunlight can be good for your health & Always & 38 \\
\hline & Sometimes & 62 \\
\hline 2. I believe that sunlight is bad for your health & Always & 1 \\
\hline & Sometimes & 66 \\
\hline & Never & 29 \\
\hline & Don’t know & 4 \\
\hline 3. I enjoy spending time outside in the sun & Often & 56 \\
\hline & Rarely & 39 \\
\hline & Never & 4 \\
\hline \multirow[t]{3}{*}{ 4. I sunbathe } & Never & 69 \\
\hline & Rarely & 25 \\
\hline & Often & 4 \\
\hline \multirow[t]{4}{*}{ 5. I use sunscreen when going outside } & Always & 24 \\
\hline & Sometimes & 44 \\
\hline & Rarely & 20 \\
\hline & Never & 12 \\
\hline \multirow[t]{5}{*}{ 6. My primary reason for avoiding the sun is: } & Custom or religion & 1 \\
\hline & Public health messages & 30 \\
\hline & Specific health reasons & 15 \\
\hline & To avoid dark skin & 19 \\
\hline & Do not avoid the sun & 35 \\
\hline \multirow[t]{4}{*}{ 7. I would spend more time in the sun if ... } & I wasn't worried about skin cancer & 49 \\
\hline & I had more time & 24 \\
\hline & I had more privacy & 9 \\
\hline & I would not spend more time in the sun & 29 \\
\hline
\end{tabular}

Table 2 Responses to the Health Motivation statements ( $n$ 140)

\begin{tabular}{llr}
\hline Health Motivation statement & Agree/strongly agree (\%) & Neutral (\%) \\
\hline 1. I eat a well-balanced diet & $39 \cdot 7$ & $41 \cdot 9$ \\
2. I look for new information related to health & $82 \cdot 4$ & $13 \cdot 2$ \\
3. Keeping healthy is very important for me & $94 \cdot 1$ & $2 \cdot 2$ \\
4. I try to discover health problems early & $75 \cdot 0$ & $19 \cdot 1$ \\
5. I have a regular health check-up even when I'm not sick & $33 \cdot 1$ & $25 \cdot 0$ \\
6. I follow recommendations to keep healthy & $70 \cdot 6$ & $22 \cdot 8$ \\
\hline
\end{tabular}


less than the currently recommended level of vitamin D, suggests a problem in this particular ethnic group. There is an increased risk, not only of bone disease later in life, but also a range of other disease conditions now being linked to vitamin D deficiency. It is already acknowledged that this population group is particularly vulnerable to at least two of these diseases - type 2 diabetes and $\mathrm{CVD}^{(21)}$.

As there is no fortification of the food supply with vitamin D in New Zealand, and dietary contribution of vitamin D is minimal, endogenous synthesis or supplemental vitamin D are the only realistic sources for this population. The participants who reported taking dietary supplements, either cod-liver oil, multivitamins or vitamin D packaged with calcium, were not achieving recommended serum levels. It has been shown that a supplemental dose of at least $25 \mu \mathrm{g}(1000 \mathrm{IU}) / \mathrm{d}$ is required to increase serum $25(\mathrm{OH}) \mathrm{D}_{3}$ from levels of moderate or severe deficiency to $50 \mathrm{nmol} / \mathrm{l}^{(26)}$.

It would seem that South Asian women living in New Zealand are not getting sufficient sun exposure to synthesise adequate levels of vitamin D. Concerns about the strength of the New Zealand sun and the risk of skin cancer were the most prevalent reasons for avoiding sun. Although $29 \%$ of respondents said that they would not spend more time in the sun, $49 \%$ indicated they would spend more time in sun if they were not afraid of skin cancer.

In a small, qualitative study in a group of South Asian women ( $n$ 23) living in Auckland, Pettit (2007) $)^{(27)}$ also found a high awareness of the risks of sun exposure in New Zealand, and of the sun safety messages which flood the media throughout spring and summer. She argues that this high level of awareness has resulted in a heightened perception of personal risk. The responses to the Health Motivation questionnaire suggest that considerable importance is placed on being healthy and obtaining information about health risks, with $82.4 \%$ saying that they look for new information related to health, and over $70 \%$ following recommendations to keep healthy. Few of these women, however, indulge in pre-emptive health checks and are therefore unlikely to have their vitamin D status checked.

There is reality behind the perceptions of the stronger New Zealand sun. The global solar ultraviolet index (UVI) has been designed as a simple measure of ultraviolet radiation (UVR) at the earth's surface ${ }^{(9)}$. The UVI is a scale which predicts the maximum daily level of UVR with values of $8-10$ regarded as very high, and $\geq 11$ as extreme. Peak UVI values in the New Zealand summer can reach 14 , up to $40 \%$ higher than those at corresponding latitudes in North America. This is due, in part, to the elliptical orbit of the earth which brings it closer to the sun during the southern hemisphere summer ${ }^{(28)}$. Lower levels of air pollution also contribute, as does the thinning of the ozone layer over New Zealand in spring ${ }^{(29)}$. Although no direct comparison can be made with India, all these factors would potentiate a lower UVI in many Indian locations, especially urban areas where high levels of pollution have been shown to impact on vitamin D status in children ${ }^{(30)}$.

In 2005, the Sunsmart ${ }^{\mathrm{TM}}$ Partnership published a position statement on the Risks and Benefits of Sun Exposure in New Zealand. This document acknowledges the health implications of too little sun exposure, but states, 'There is no evidence that the sun protection messages promoted in New Zealand have affected vitamin D levels,(31). More recently, the Cancer Society of New Zealand (2008) has announced plans to develop a range of healthy sun exposure messages, that take into account season, skin type, time of day and related research findings as they emerge $^{(32)}$. Since late 2007 there has been an information sheet on the Cancer Society web site about sun exposure for people with dark skin ${ }^{(33)}$.

To a lesser degree, lifestyle, cultural and personal appearance reasons also featured as reasons to avoid the sun. A number of women commented on long work hours, working in an office, and driving to and from work. Of the respondents, $24 \%$ said that they would spend more time in the sun if they had more time. Pettit also found that amongst the married women in her study, time and opportunity were important constraints ${ }^{(27)}$.

Despite the seasonal variation, the majority were still failing to reach concentrations $>50 \mathrm{nmol} / \mathrm{l}$, even those tested at the end of summer. An assessment of serum $25(\mathrm{OH}) \mathrm{D}$ concentrations in the New Zealand population also showed seasonal variation with a difference (in women) of $31 \mathrm{nmol} / 1$ between summer and spring ${ }^{(12)}$. Above latitudes of $40^{\circ}$ it is not possible to make vitamin D during winter, and $25(\mathrm{OH}) \mathrm{D}$ levels in summer can be 20-120\% higher $^{(34)}$.

Low levels of vitamin D have been seen in other migrant South Asian populations in Denmark and Britain $^{(35,36)}$; however, these populations were subject to much lower UVI than the present study population in Auckland, New Zealand. It is probably more useful to compare the vitamin D levels of these South Asian women to other brown-skinned ethnic groups in New Zealand. Rockell et al. ${ }^{(12)}$ found the mean $25(\mathrm{OH}) \mathrm{D}$ concentration in New Zealand, European and other women (adjusted for age, ethnicity, season, region and $\mathrm{BMI})$ to be $49 \mathrm{nmol} / \mathrm{l}$, compared to Maori women at $38 \mathrm{nmol} / 1$ and Pacific women at $33 \mathrm{nmol} / 1$. Mean serum vitamin $\mathrm{D}$ concentration in participants of the present study was 32 (19) nmol/l.

There is currently much debate around the use of $50 \mathrm{nmol} / \mathrm{l}$ as the cut-off for sufficiency, and scientists working in vitamin D research have recently called for this minimum to be raised to $80 \mathrm{nmol} / \mathrm{l}^{(37)}$. None of the participants in the present study met that criterion for adequacy.

In conclusion, the present study shows that we can no longer afford to assume that vitamin D levels in the population will be concurrent with environmental UVR. 
Some groups, such as South Asians, are at higher risk of hypovitaminosis $\mathrm{D}$, due, in part, to deliberate avoidance of sun exposure, a lifestyle that allows little or no incidental sun exposure, and lack of fortification of the food supply. Such groups are especially vulnerable during winter and spring.

\section{Acknowledgements}

The present study was funded by the NZ Lotteries Board from their Lotteries Health fund. P.R.H. is funded by a Massey University Doctorate Scholarship. The authors declare that there are no conflicts of interest. The authorship responsibilities are as follows: P.R.H. and J.C. conceived the study, acquired funding and ethics approval. P.R.H. coordinated recruitment, participant management and data collection. W.S. designed the laboratory protocol. P.R.H. drafted the manuscript. All authors were involved in revising the manuscript and all read and approved the final manuscript. The authors would like to thank the 239 participating women and Dr R Sood (Mount Roskill Surgical and Medical Centre), Midi Tsai, Laura King and Hymavathy Danthala (Massey University Post Graduate students).

\section{References}

1. Holick MF \& Chen TC (2008) Vitamin D deficiency: a worldwide problem with health consequences. Am J Clin Nutr 87, 1080S-1086S.

2. Allgrove J (2004) Is nutritional rickets returning? Arch Dis Child 89, 699-701.

3. Al Faraj S \& Al Mutairi K (2003) Vitamin D deficiency and chronic low back pain in Saudi Arabia. Spine 28, 117-119.

4. Plotnikoff GA \& Quigley JM (2003) Prevalence of severe hypovitaminosis $\mathrm{D}$ in patients with persistent, nonspecific musculosketal pain. Mayo Clin Proc 78, 1463-1470.

5. Blok BH, Grant CC, McNeil AR \& Reid IR (2000) Characteristics of children with florid vitamin D deficient rickets in the Auckland region in 1998. NZ Med J 113, 374-376.

6. Nozza JM \& Rodda CP (2001) Vitamin D deficiency in mothers of infants with rickets. Med J Aust 175, 253-255.

7. Robinson PD, Hogler W, Craig ME, Verge CF, Walker JL, Piper AC, Woodhead HJ, Cowell CT \& Ambler GR (2006) The re-emerging burden of rickets: a decade of experience from Sydney. Arch Dis Child 91, 564-568.

8. Bradley B (1999) The Penguin New Zealand Atlas for the 21st Century [Terralink NZ Ltd, editor]. Auckland: Penguin Books.

9. World Health Organization (2002) Global Solar UV Index, A Practical Guide. Geneva: WHO.

10. Rockell JE, Green TJ, Skeaff CM et al. (2005) Season and ethnicity are determinants of serum 25-hydroxyvitamin D concentrations in New Zealand children aged 5-14 y. J Nutr 135, 2602-2608.

11. Judkins A \& Eagleton C (2006) Vitamin D deficiency in pregnant New Zealand women. NZ Med J 119, U2144.

12. Rockell J, Skeaff C, Williams S \& Green T (2006) Serum 25-hydroxyvitamin D concentrations of New Zealanders aged 15 years and older. Osteoporos Int 17, 1382-1389.
13. Statistics New Zealand (2006) 2006 Census of Population and Dwellings - Asian People. New Zealand: New Zealand Government.

14. Australian Bureau of Statistics (2006) Migration and ethnicity. http://www.abs.gov.au/AUSSTATS/abs@.nsf/ Lookup/3416.0Main+Features22008\#Anchor2 (accessed February 2009)

15. Visser M, Deeg D \& Lips P (2003) Low vitamin D and high parathyroid hormone levels as determinants of loss of muscle strength and muscle mass (sarcopenia): the longitudinal aging study Amsterdam. J Clin Endocrinol Metab 88, 5766-5772.

16. Grant WB (2002) An estimate of premature cancer mortality in the US due to inadequate doses of solar ultraviolet-B radiation. Cancer 94, 1867-1875.

17. Wang TJ, Pencina MJ, Booth SL et al. (2008) Vitamin D deficiency and risk of cardiovascular disease. Circulation 117, 503-511.

18. Munger KL, Zhang SM, O’Reilly E, Hernán MA, Olek MJ, Willett WC \& Ascherio A (2004) Vitamin D intake and incidence of multiple sclerosis. Neurology 62, 60-65.

19. Hyppönen E, Läärä E, Reunanen A, Järvelin M-R \& Virtanen SM (2001) Intake of vitamin D and risk of type 1 diabetes: a birth-cohort study. Lancet 358, 1500-1503.

20. Borissova A, Tankova T, Kirilov G, Dakovska L \& Kovacheva R (2003) The effect of vitamin D3 on insulin secretion and peripheral insulin sensitivity in type 2 diabetic patients. Int J Clin Pract 57, 258-261.

21. Ministry of Health, N.Z. (2006) Asian Health Chart Book 2006. Public Health Intelligence: Monitoring Report no.4, p. 47. Wellington: Ministry of Health.

22. Von Hurst PR, Stonehouse W, Matthys C, Conlon C, Kruger MC \& Coad J (2008) Metabolic syndrome, vitamin D and bone status in South Asian women living in Auckland, New Zealand: a randomised, placebo-controlled, double-blind vitamin D intervention. BMC Public Health 8, 267.

23. Kim K, Horan M, Gendler P \& Patel M (1991) Development and evaluation of the osteoporosis health belief scale. Res Nurs Health 14, 155-163.

24. Wu F, Staykova T, Horne A et al. (2003) Efficacy of an oral 10-day course of high dose calciferol in correcting vitamin D deficiency. NZ Med J 116, U536.

25. Working Group of the Australian and New Zealand Bone and Mineral Society, Endocrine Society of Australia, and Osteoporosis Australia (2005) Vitamin D and adult bone health in Australia and New Zealand: a position statement. Med J Aust 182, 281-285.

26. Vieth R, Chan P-CR \& MacFarlane GD (2001) Efficacy and safety of vitamin $\mathrm{D}_{3}$ intake exceeding the lowest observed adverse effect level. Am J Clin Nutr 73, 288-294.

27. Pettit FS (2007) Factors influencing sun exposure behaviours and the risk of vitamin D deficiency among Pacific and South Asian women aged 18 to 40 living in Auckland. Masters Thesis, The University of Auckland.

28. McKenzie R, Bodeker G, Scott G, Slusserb J \& Lantzc K (2006) Geographical differences in erythemally-weighted UV measured at mid-latitude USDA sites. Photochem Photobiol Sci 5, 343-352.

29. Liley JB \& McKenzie RL (2006) Where on Earth has the highest UV? NIWA UV Workshop 2006. http://www.niwa. cri.nz/rc/atmos/2006/papers (accessed July 2008).

30. Agarwal KS, Mughal MZ, Upadhyay P, Berry JL, Mawer EB \& Puliyel JM (2002) The impact of atmospheric pollution on vitamin D status of infants and toddlers in Delhi, India. Arch Dis Child 87, 111.

31. The Sunsmart Partnership (2005) Position statement: The risks and benefits of sun exposure in New Zealand. http:// www.sunsmart.org.nz/skin-cancer-control-in-nz/positionstatements/risks-and-benefits-of-sun-exposure.aspx (accessed July 2008). 
32. Cancer Society of New Zealand (2008) The Cancer Society's position on vitamin D, sun exposure and cancer. http://www.cancernz.org.nz/HealthPromotion/SkinCancer Control/VitaminD/ (accessed July 2008).

33. Cancer Society of New Zealand (2008) Ultraviolet (UV) radiation and vitamin D - A special note for people with dark skin. http://www.cancernz.org.nz/HealthPromotion/ SkinCancerControl/VitaminD/ (accessed July 2008).

34. Porojnicu A, Robsahm T, Dahlback A, Berg J, Christiani D, Bruland O \& Moan J (2007) Seasonal and geographical variations in lung cancer prognosis in Norway. Does vitamin D from the sun play a role? Lung Cancer 55, 263-270.
35. Andersen R, Mølgaard C, Skovgaard L, Brot C, Cashman K, Jakobsen J, Lamberg-Allardt C \& Ovesen L (2008) Pakistani immigrant children and adults in Denmark have severely low vitamin D status. Eur J Clin Nutr 62 625-634.

36. Roy DK, Berry JL, Pye SR, Adams JE, Swarbrick CM, King Y, Silman AJ \& O'Neill TW (2007) Vitamin D status and bone mass in UK South Asian women. Bone 40, 200-204.

37. Vieth R, Bischoff-Ferrari H, Boucher BJ et al. (2007) The urgent need to recommend an intake of vitamin $\mathrm{D}$ that is effective. Am J Clin Nutr 85, 649-650. 